\title{
SUPPORT FOR TEACHERS IN CHALLENGING SITUATIONS AS A FACTOR OF CHANGE: REFLECTIONS FROM A CONTINUING PROFESSIONAL DEVELOPMENT PROGRAMME IN GUINEA-BISSAU
}

\author{
Rui da Silva ${ }^{1}$ \\ Center for African Studies, University of Porto, Portugal \\ Joana Oliveira \\ Polytechnic Institute of Viana do Castelo, Portugal \\ Center for African Studies, University of Porto, Portugal
}

\begin{abstract}
This article focuses on the experience of a bilateral educational aid project concerning a continuing professional development (CPD) programme for teachers with specific reference to Guinea-Bissau. The authors were keen to understand how teachers and school principals perceived the impact of this CPD programme on the quality of teaching and learning. In this qualitative study, data from teachers and school principals were collected by means of interviews, focus groups and field notes. The article argues that the programme improved the language skills of the teachers and impacted positively on scientific, pedagogical, and didactic content.
\end{abstract}

Keywords: teachers; professional development; fragility; Guinea-Bissau

\section{Introduction}

Quality education for all is a global concern, a human right and it is closely related to the education for all agenda stated in the Jomtien (1990) and Dakar (2000) Declarations. Given what can be considered the "global learning crisis", the post-2015 education for all development goals put the improvement of the quality of education at the centre of the discourse (UNESCO, 2014).

In order to achieve equitable and good quality education teachers play a critical role, specifically as key agents for the improvement in the achievements of learners (Christie, Harley, \& Penny, 2010; Flores \& Simão, 2009; O’Sullivan, 2006). Taking this into consideration the continuing professional development (CPD) of teachers, particularly in developing countries, may function as a non-monetary compensation and can play an important role in enhancing and/or introducing knowledge and skills.

${ }^{1}$ Correspondence: Via panorâmica, s/n, 4150-564 Porto - Portugal; Email: rdasilva.email@gmail.com 
Continuing education credits are required in many school systems and this approach to value-added education has been recognized (Bainton, Barrett, \& Tikly, 2016; Benavente \& Varly, 2010; Coleman, 2014).

In contexts of protracted crises and fragility teachers face tough working conditions and are often paid on an irregular basis, underpaid or not paid at all (Burns \& Lawrie, 2015; INEE, 2009; Lundy, 2018). The setting up of CPD programmes in these contexts faces a variety of challenges, are often episodic and are based on workshops or short course training with practically no follow-up to monitor the practices of teachers (Burns \& Lawrie, 2015).

This article explores how teachers and school principals perceived the impact of a CPD programme on the quality of teaching and learning. The CPD programme under scrutiny was a long term school-based programme (2002-2012) developed in a context of fragility and political uncertainty and based on the experience of a bilateral educational aid programme in Guinea-Bissau - PASEG (Programa de Apoio ao Sistema Educativo da Guiné-Bissau) [Aid Programme for the Educational System of GuineaBissau]. In this study data collection involved semi-structured interviews with school principals, focus groups with the participating teachers and field notes taken during meetings, informal conversations and observations. The data was collected during intermittent periods of field research carried out between 2009 and 2014 during at least ten field visits to Guinea-Bissau. Also in the period 2009 to 2012 the researchers were actively involved in the programme, as a consultant. The ethical issues raised by taking on the roles of both researcher and consultant are addressed in the article.

The article is organised into four main parts. Following these introductory notes, the article first provides a brief country overview followed by the conceptual framework. Following this overview is an explanation of the research methods and then a discussion of the findings. The fourth and final part presents the main conclusions of the study.

\section{Context}

To put the research for this paper into context, it is necessary to give a brief overview of the country and the programme under scrutiny.

\section{Previous research on professional development of teachers in Guinea-Bissau}

Few studies have examined the professional development of teachers in GuineaBissau and this country is underrepresented in comparative and international education journals. In general, and from the research conducted so far regarding professional development, it can be concluded that the first national initiative started in 1975 (one year after independence) with the creation of Study Committees (Comissões de Estudo) ${ }^{2}$. The professional development of teacher's initiatives/programmes were/are promoted/ financed by donors, UNICEF and international NGOs. In general these professional development initiatives can be considered discontinuous, unarticulated and with little or no impact on teaching practice or the career progression of teachers and they have been responsible for producing unrealistic expectations with regard to their impact on the quality of teaching (Andersson-Brolin, Catela, Fernandes, \& Liljeson, 1990; Aveleira, 2006; Barbosa \& Bizarro, 2011; Barreto, 2012; Benavente \& Varly, 2010; Campos \& Furtado, 2009; Candé, 2008; Correia, 2013; Costa, 2014; Cá, 2005; Daun, 1997; Dâmaso, 1997; R. Landim \& Bamba, 1994; Lepri, 1988; Medeiros, 2005; Monteiro, 2005; Oliveira, 2014; Oliveira, Lanceros-Mendez, Neves, \& Santos, 2012; G. Portugal \& Aveleira, 2007; M. G. Portugal \& Aveleira, 2009; Rosabal, 2005; Santos, Silva, \& Mendes, 2012).

\footnotetext{
${ }^{2}$ This initiative is like what in other contexts is called lesson study, where teacher co-learning, through
} mutual collaboration and feedback, is usually conducted under the leadership of an experienced teacher. 
The research conducted so far about Guinea-Bissau discloses several challenges faced by teachers. In general, the teachers face many constraints in coping with the official/instructional language (Portuguese) and with the subjects of mathematics, social, and civic education (Campos \& Furtado, 2009; Cá, 2005; Freire, 1984; Furtado, 2005; R. Landim \& Bamba, 1994; R. C. Landim, 2010; Lundy, 2013; Monteiro, 2005; Namoni, 1994; Pereira \& Namoni, 1994; Pityana, 2013).

When initiatives like the Study Committees were examined, it could be seen that these initiatives were revitalised in 1997 by a World Bank project. This led to an improvement of lesson planning by teachers and teaching methods (Rosabal, 2005). It was also clear from these studies under review that the teachers predominantly used the blackboard, oral presentation of the subjects, textbook exercises (when they are available) and student evaluation was by means of written tests.

This paper fits into the ongoing conversation about CPD in Guinea-Bissau and complement the priviest studies. This stems from the fact that it analysed the impact and effects of the most systematic and longest CPD programme in Guinea-Bissau from the last 20 years.

\section{PASEG and the involvement in teacher training}

The programme under scrutiny, PASEG, had two phases and it was implemented over 12 years from 2000 to 2012. The first phase covered the school years $2000 / 2001$ to $2008 / 2009$ and the second phase school years 2009/2010 to 2011/2012 (Santos, Silva, \& Mendes, 2014). PASEG was a bilateral programme between the Portuguese and the Guinea-Bissau Governments that was developed after a political decision was made to fill the lack of qualified human resources in the Guinea-Bissau educational system ${ }^{3}$.

In the school year 2006/2007, the PASEG started the first structured approach to the CPD of teachers with the development of Pedagogical Support Groups (Grupos de Acompanhamento Pedagógico) (IPAD, 2011; Santos et al., 2012). Up to the school year 2008/2009 teachers from Grade 7 to Grade 11 were involved and from school year 2009/2010 onwards teachers from Grade 1 to Grade 12 were involved. The subjects covered in this CPD programme were philosophy (until 2011), physics, Portuguese language, mathematics, chemistry and biology (Afonso, Magalhães, Ribeiro, \& Monteiro, 2008; IPAD, 2011; Santos et al., 2012).

The Pedagogical Support Groups until 2009 were an initiative that allowed teachers to meet with an expatriate teacher trainer to prepare lesson plans, produce and select pedagogical materials for the classes and promote collaborative work among teachers (PASEG, 2007). During this period some of these groups promoted issues related to teaching methods and pedagogical exchanges among teachers. However these issues were limited to those expatriates that promoted this approach (Afonso et al., 2008; IPAD, 2011). An agreement was established between PASEG and the Ministry of Education to reduce the timetable of the teachers by four hours per week in order to allow them to take part in the Pedagogical Support Groups. In the second phase this agreement was kept and included a reduction of 3 hours per week for the teachers from Grades 1 to 6 (Santos et al., 2012).

In the second phase of PASEG the Pedagogical Support Groups were redesigned and defined as a strategy for the CPD of teachers based in schools. It was established that the Pedagogical Support Groups followed a didactical and pedagogical approach focused mainly on four issues: pedagogy, scientific subject content, material production and collaborative work among teachers (Santos et al., 2012). It also included lesson

\footnotetext{
${ }^{3}$ For a deeper analysis of PASEG and to explore the embedded theory and praxis see Silva \& Oliveira, 2017
} 
observation by the CPD Programme trainer based on the pedagogical supervision framework. The pedagogical supervision framework included meetings before and after the class observation (training sessions), class observation, and meeting after class observation with the trainer to critically reflect about the class. This circle appended in a continuum.

This restructuring also specified that the Pedagogical Support Groups from Grades 7 to 12 should have a yearly total of 80 to 100 hours of training and from Grades 1 to 6 a total yearly training of 64 hours. The Pedagogical Support Groups also included class support by the trainers and the final evaluation was based in the assessment of a portfolio produced by the teachers during the training (Santos et al., 2012).

In this phase the PASEG was also negotiating with the Ministry of Education for Pedagogical Support Group certification in order to link this to the career progression of teachers (Santos et al., 2012).

\section{Conceptual framework}

The CPD of Teachers is a complex process, where the teacher is always at the centre of the whole process. In this way teachers act as both a subject and an object of learning (Avalos, 2011; Flores \& Simão, 2009). In a broad perspective CPD provides teachers with opportunities to learn for extended periods of time in a cyclical way. These learning opportunities should be contextualized and can be formal and/or informal. Teachers involved in CPD initiatives can be in groups and/or on an individual basis following a continuous process of learning professional skills. As a consequence, CPD should lead to changes and innovation in schools (Avalos, 2011; Flores \& Simão, 2009; Lopes \& Silva, 2010; Villegas-Reimers, 2003). The CPD of teachers is considered critical for improving the quality of education and student achievements. In this way, CPD promotes the pedagogical development, self-knowledge, and self-understanding of teachers. Also teachers develop new cognitive, theoretical, and analytical skills (Avalos, 2011; Flores \& Simão, 2009).

The communities of practice are also powerful CPD strategies because allow different ways of es organization and design enabling teachers to be and live in the profession in various ways. The communities of practice "are groups of people who share a concern or a passion for something they do and learn how to do it better as they interact regularly" (Wenger \& Wenger-Trayner, 2015, p. 1). Nevertheless, communities of practice come in a variety of forms and can follow a three-layer model where each layer is a prerequisite to the following: breaking of isolation; improvement of teaching and/ or research; professional development regarding research and teaching (Hadar \& Brody, 2010).

Context sensitivity is one important aspect that must be taking in consideration when designing CPD programmes, acknowledging socio-cultural capital by ensuring that educational initiatives and projects seriously consider local contexts and realities (Lundy, 2013). This arises from the fact that the CPD worldwide is very diverse and "teachers engaging in professional development in the Namibian study may not be relevant to teachers in Canada or The Netherlands" (Avalos, 2011, p. 17). Another aspect that arises from research is that long term interventions are more effective than shorter ones (Avalos, 2011). However, the traditional INSET is still in use in contexts of protracted crises and fragility (Burns \& Lawrie, 2015). In these contexts CPD programmes are often episodic and based on workshops or short term training with practically no follow-up to monitor the practices of teachers (Burns \& Lawrie, 2015).

The CPD of teachers also has the power to allow teacher co-learning in a first phase in an informal manner and then, through networking and exchanges between schools, in formal CPD settings (Avalos, 2011). This is important, because evidence from research suggests that an effective way for teachers to learn is to co-learn through 
observation and feedback (e.g. Avalos, 2011; Geldenhuys \& Oosthuizen, 2015; Hardman et al., 2015).

In many cases in the African context the CPD pays attention to the academic qualification of teachers. This issue arises, because of the generally low qualification of teachers. In this way the CPD goals are altered (Christie et al., 2010; Hardman, Ackers, Abrishamian, \& O'Sullivan, 2011).

Several studies in the African context (e.g. Tanzania, Kenya, Uganda, South Africa, Zambia) highlight that CPD programmes that combined school-based training and opportunities to learn over extended periods of time, among others, contribute more meaningfully to the improvement of the pedagogical skills of teachers (e.g. Geldenhuys \& Oosthuizen, 2015; Hardman et al., 2011; Hardman et al., 2015; Haßler, Hennessy, Cross, Chileshe, \& Machiko, 2015). However, the inclusion of lesson observation can be critical for improving and measuring quality (Hardman et al., 2015; O'Sullivan, 2006). In lesson observation the principles of pedagogical supervision must be taken into consideration. This stems from the fact that pedagogical supervision is a process that allows the teachers to overcome their lesson difficulties on a daily basis. In this way the supervisor should learn "the skills of working with groups to solve instructional problems" (Glickman \& Gordon, 1998, p. 323). Nevertheless, it is necessary to overcome the prejudice that supervision is a control tool (De Grauwe, 2007). Another critical aspect is to "recognize a supervisory model as a dynamic process, or a metaphor, for a journey toward professional growth for all educators."(Snow-Gerono, 2008, p. 1508).

In broad terms, and taking in consideration the priviest studies, in order to improve the results from teacher professional learning and development the programmes should have the following features:

- Direct involvement of teachers in discussions about the concepts taking into account their background, beliefs, ideas and expectations concerning the students;

- Integration of theory and practice;

- If the programme is developed in the school environment, it is important that the educational leaderships are actively involved;

- To improve the practices of teachers it is important that the programme is developed for extended periods of time and promotes multiple opportunities for learning;

- The programme environment should be characterised by trust and challenge; and

- Involvement of external expertise with regard to the group of teachers.

\section{Methodology and data collection}

This study made use of a qualitative research design in order to understand how teachers and school principals perceived the impact of this CPD programme in teaching and the quality of learning.

Evaluation plays a key role in regard to development assistance projects, in particular impact assessment - developmental evaluations. This stems from the fact that "Policymakers are not only interested in 'evidence-based policy', but also wish to judge the effectiveness of specific interventions" (Befani, Ramalingam, \& Stern, 2015, p. 1). The developmental evaluations usually follow the OECD DAC criteria - relevance, effectiveness, efficiency, impact and sustainability (Andersen, 2014; Feinstein \& Beck, 2007; Picciotto, 2014). Presently there is a renewed emphasis on measurement and certain evaluation methods, particularly experimental or quasi-experimental methods. In this way the quantitative methods are identified as having greater validity assuming the randomized controlled trials, followed by quasi-experiments, mixed methods and 
qualitative methods the most common used (Befani, Barnett, \& Stern, 2014). Because the focus of this paper is an in-deep understanding how teachers and school principals perceived the impact of this CPD programme on the quality of teaching and learning, and not a developmental evaluation, deviates from the OECD-DAC criteria or experimental methods.

The data in this article derived from intermittent periods of field research carried out between 2009 and 2013 during at least eight field visits to Guinea-Bissau. In the period from 2009 to 2012 the researchers were involved in the programme as consultants ${ }^{4}$. However, the authors were aware of the ethical issues involved in playing both roles and were particularly wary of the risks of bias. The processes of data collection and analysis were consequently subjected to external, independent academic appraisal through ongoing critical discussion with two other researchers. This guarded against the risk of selective data identification and analysis.

Three types of data were collected during this research. The data sources were: semi-structured interviews with school principals, focus groups of teachers. Field notes were also used. Four public schools, 71 teachers and four school principals, who participated in the CPD programme, were selected for the research. There were 59 males and 16 females.

School 1 was a public school founded in 1983 and located in an urban area in one of the Guinea-Bissau regions. 72 teachers and 3,481 students worked in this school from the seventh to the twelfth grades. The CPD programme started in the school year $2010 / 2011$.

School 2 was a public school founded in 1999 and located in one of the most populated neighbourhoods of the capital city, Bissau. In this school are 155 teachers and 5,685 students from the first to the twelfth grades. The CPD programme started in the school year 2005/2006 for post-basic education teachers.

School 3 was a public school founded in 1989 and located in another neighbourhood of Bissau. Here another 136 teachers and 4,202 students also worked from the first to the twelfth grades. The CPD programme started in the school year 2009/2011 for primary education teachers.

School 4 was another public school, which was founded in 1958 and located in the capital city centre. In this school are 170 teachers and 4,895 students from the seventh to the twelfth grades. The CPD programme started in the school year 2006/2007.

The content analysis of the interviews and focus groups was open and the categories emerged from the data (Bardin (2007).

Ethical concerns were addressed through informed consent, the guarantee of, anonymity and the right to unconditional withdrawal from the research process at any stage (BERA, 2011; CEUM, 2012; Cohen, Manion, \& Morrison, 2009; Robson, 2011).

\section{Findings and discussion}

This section discusses the main findings by school and compares differences and common points between the schools. It also discusses how teachers and school principals perceived the impact of this CPD programme in teaching and on the quality of learning.

\section{School 1}

\footnotetext{
${ }^{4}$ The consultancy services were related to the programme pedagogical and scientific issues that were not directly linked to the study participants and did not affect the continuation of the Programme support. The consultant role was the entry point to the schools under analysis and the study participants were not pressured to provide data for the research in order to continue the consultancy services.
} 
All the participating teachers commented that the CPD programme had an impact and effects in their school, on the students and in their daily practices. The perception of the school principal was similar. In this regard the school principal stated that:

We had good learning results. The students achieved better results with the support that the teachers had from the Pedagogical Support Groups. The student results were much better than in previous years. If we go to the results from the first national exams in 2011, our school had the best scores nationally. This is a consequence of the PASEG intervention in the school, because the best results were in Portuguese language and mathematics, the subjects on which the Pedagogical Support Groups worked. [School 1 Principal - authors translation].

Discussions revealed that the CPD programme allowed, in particular, for the inclusion of local trainers and lesson observation to:

- Improve the use of Portuguese language;

- Change the way the daily class plan was organised;

- Change the way the teaching content was selected;

- Allow the teacher to have access to teaching aids;

- Change the pedagogical strategies adopted;

- Change the way the students were evaluated;

- Promote collaborative work among teachers;

- Promote curricular mediation ${ }^{5}$;

- Improve the specific scientific subject knowledge in mathematics and Portuguese language;

- Improve the student results;

- Improve the results in the national exams; and

- Allow for the opportunity to have access to a CPD programme on the school premises.

The school principal also commented that teachers from two schools from the rural area in the region also were involved in the CPD programme. This involvement was informal, because they attended the training at their own expense and without being part of the direct target group. Nevertheless, their willingness to participate at their own expense suggests that the program was effective.

The improvement of Portuguese language promoted the de facto improvement of the knowledge of teachers of the language, while at the same time it increased their empowerment to speak it on a daily basis. In the words of the teachers:

We learned a lot in terms of planning. We knew how to plan but we learned new things. We learned how to introduce the contents to our students. [Teacher 1 School 1 - authors translation]

\footnotetext{
${ }^{5}$ By curricular mediation we refer to the role developed by the textbooks and other supporting aids, which allowed the teachers to work without using the official curriculum and to teach the same content (Pacheco, 2003).
} 
The teachers were 10 to 15 years teaching without attending training. The Pedagogical Support Groups broke this cycle. [Teacher 2 School 1 authors translation]

The Pedagogical Support Groups helped the teachers a lot to follow a curriculum, because, in practice, each teacher chose the class content on their own. With the materials and teaching aids we all followed the same content. In this way, if we add a national exam, we were all at the same point. [Teacher 3 School 1 - authors translation]

Teachers confirmed that the benefits of this CPD programme also reached other teachers and schools indirectly. This stems from the fact that:

We could in the meetings at the regional level transmit the training session content and materials to our colleagues from other schools. [School 1 Principal - authors translation]

Some negative effects of the CPD programme were identified; namely:

- The training attendance certificates were not delivered;

- The students did not have access to materials; and

- The CPD programme should have included other subjects in addition to mathematics and Portuguese language.

\section{School 2}

All participating teachers stated that the CPD programme had an impact and effects in their school, on the students and in their daily practices. The subjects involved were mathematics, Portuguese language and biology. The school principal had a similar perception, even though it seems that there were some difficulties in reconciling the timetables of the teachers to allow them to attend the training.

Many participants perceived that the organisation of the CPD programme had changed, since its beginning. In a first phase the teachers developed their annual and weekly lesson plans. The sessions involved the selection of the content for the lessons and clarification of the scientific concerns of the teachers about the content of specific lessons.

Nerveless, the teachers stated that in this period one of the trainers adopted a different model including observations of lessons by the trainer of the trainees. In the words of the teachers:

The Pedagogical Support Groups were important, because they showed us how to plan and how we could teach good classes to our students. They also gave us teaching aids and helped us to correct our daily plans and sometimes they watched our classes and helped us to improve [Teacher 1 School 2 - authors translation]

This Pedagogical Support Groups helped me to recycle my knowledge about my subject content and the way I planned my classes. We learned a lot by exchanging experiences in the training sessions. [Teacher 2 School 2 - authors translation] 
In the second phase, when the CPD programme was systematised and reorganised, it functioned in a different way. Discussions revealed that the CPD programme, in particular, allowed for the inclusion of local trainers and lesson observations to:

- Improve the use of Portuguese language;

- Change the way the daily class plan was organised;

- Change the way the teaching content was selected;

- Allow the teachers access to teaching aids and ICT;

- Change the pedagogical strategies adopted;

- Change the way the teachers evaluated their students;

- Promote collaborative work among teachers;

- Promote curricular mediation;

- Improve the specific scientific subject knowledge in mathematics, biology and Portuguese language;

- Allow the opportunity to have access to a CPD programme on the school premises; and

- Introduce the issues of citizenship and environmental education.

With regard to curricular mediation it seems that this school started by adopting materials and teaching aids from the most prestigious private school in the country. However, these materials were produced by the expatriate trainer from this CPD programme. In this case there was a second level of curricular mediation. This materials and teaching aids sharing also suggests PASEG importance and success.

The improvement of Portuguese language promoted the de facto improvement of the knowledge of the teachers of the language and at the same time it helped their empowerment in speaking it on a daily basis. In the words of the teachers:

We - from mathematics - learned a lot from the Pedagogical Support Groups. The training allowed us to exchange experiences but with the help of the trainers this exchange became easier. They also provided us with teaching materials that helped to improve our teaching and helped us with specific subject content issues. [Teacher 3 School 2 - authors translation]

The Pedagogical Support Groups helped us to unify the curriculum. Before the teachers sometimes had different curriculums and each one taught what they wanted [Teacher 4 School 2 - authors translation]

Negative effects of the CPD programme that were identified were:

- The CPD programme should include other subjects in addition to mathematics, biology and Portuguese language; and

- The CPD programme should include tenth, eleventh and twelfth grade classes.

\section{School 3}

From the data it emerged that the participants considered that the CPD programme had an impact and effects in their school, on the students and in their daily practices. The teachers involved were from Grades 1 to 6 . Taking into consideration that in Guinea-Bissau from Grade 1 to 6 one teacher is in charge of teaching all subjects, 
this training covered all subjects. Even so, the focus was on Portuguesa language and mathematics, because they are the subjects with more content and a priority area for Portuguese Aid.

Teachers commented particularly on how this training helped them on a daily basis. Nevertheless, a teacher emphasised that the expatriate trainers also benefited from the CPD programme in the following way:

The trainers also learned from us about our way of teaching and working with our children [Teacher 1 School 3 - authors translation]

The improvement of Portuguese language promoted the de facto improvement of the knowledge of the teachers of the language but at the same time their empowerment in speaking it daily:

The improvement of the Portuguese language was very important. Now I can say that I can speak Portuguese, as I have the courage to speak Portuguese in any place. [Teacher 2 School 3 - authors translation]

Discussions revealed that the CPD programme, in particular, allowed for the inclusion of local trainers and lesson observations to:

- Improve the use of Portuguese language;

- Change the way the daily class plan was organised;

- Change the way the teaching content was selected;

- Allow the teacher to have access to teaching aids;

- Change the pedagogical strategies adopted;

- Promote collaborative work among teachers;

- Promote curricular mediation;

- Improve specific scientific subject knowledge;

- Allow the opportunity to have access to a CPD programme on the school premises; and

- Introduce the issues of citizenship and environmental education.

The curricular mediation in this school started with the adoption of the materials produced by the Ministry of Education to which the teachers did not have previous access.

Negative effects of the CPD programme that were identified were:

- The CPD programme should include monetary compensation; and

- The CPD programme should include tenth, eleventh and twelfth grade classes.

\section{School 4}

All participating teachers and the school principal commented that the CPD programme had an impact and effects in their school, on the students and in their daily practices. The subjects involved were mathematics, physics, chemistry, Portuguese language and biology.

Taking into consideration that it was in this school that the CPD programme started many participants perceived that the organisation of the CPD programme was divided into two phases. In the first phase teachers developed their annual and weekly 
lesson plans. The sessions involved the selection of the content for the lessons and clarification of the scientific concerns of the teachers about content of a specific lesson. In the second phase the CPD programme included class support by the trainers and the final evaluation based on the assessment of a portfolio made by the teachers during their training. Also a didactical and pedagogical approach with lesson observation was followed. In the words of some teachers:

After we graduated as teachers, at least from my experience, we were on our own. In this way the Pedagogical Support Groups were very good, because they helped us to prepare the planning and the teaching aids with other teachers. In this way we were not alone. [Teacher 1 School 4 - authors translation]

In the Pedagogical Support Groups, we could meet with other teachers to prepare the plans and the teaching aids. The trainers observed us in the classroom and in the end, we talked about the class. With this we learned - me in particular - learned a lot of things that I never thought that I could learn. [Teacher 2 School 4 - authors translation]

Discussions revealed that the CPD programme, in particular, allowed for the inclusion of local trainers and lesson observations to:

- Improve the use of Portuguese language;

- Change the way the daily class plan was organised;

- Change the way the teaching content was selected;

- Allow the teachers to have access to teaching aids and ICT;

- Change the pedagogical strategies adopted;

- Change the way they evaluated their students;

- Promote collaborative work among teachers;

- Promote curricular mediation;

- Improve the specific scientific subject knowledge in mathematics, biology, chemistry, physics and Portuguese language; and

- Allow the opportunity to have access to a CPD programme on the school premises.

The improvement of Portuguese language again promoted the de facto improvement of the knowledge of the teachers of the language but at the same time their empowerment in speaking it on a daily basis.

Only the school principal identified one negative aspect of the CPD programme. He mentioned that a negative outcome was the inclusion of local trainers. From the data it emerged that this strategy did not work well and there were tensions between the teachers and the school principal over the CPD programme. This aspect was only found in this particular school. In the other schools the national trainers were accepted without question. In the words of this school principal:

They told me [the programme coordinator] that the Portuguese language trainer would be a national not an expatriate. These two trainers were rejected in this school. The teachers almost did not attend the Portuguese Pedagogical Support Groups. If the trainer is a national, 
the teachers reject them, because they consider that they can only learn with the expatriate. [School 1 Principal - authors translation].

\section{Common points among the schools}

We found that globally all the participants in this research stated that the core contribution of this CPD programme was the improvement of Portuguese language and/or confidence to speak it publicly. The CPD programme also allowed the schools to provide access to teacher development opportunities on school premises and for a resource centre with ICT.

The findings suggest that the CPD programme also promoted curricular mediation that went beyond the public schools that were the target of the programme. This stems from the fact that the teachers also taught in private schools (principally in the capital city) in order to increase their income. In doing so they used the training content and teaching aids of the CPD programme in these schools. The teachers also shared the teaching aids and training materials with other teachers in their personal network, thus contributing more widely to the spread of the impact of this CPD programme. However, more research is needed concerning this matter in order to have a deeper insight of this issue and to understand the complex web of relationships between public and private schools. This aspect is amplified by the size of the country.

All the participants stated that the CPD programme contributed to a change in the way that they planned their daily classes. It also contributed to improve the way the teaching content was selected and what type of pedagogical strategies were adopted. Moreover, it was stated by the participants that the organisation of the training sessions was similar in the second phase of PASEG (that followed a didactical and pedagogical approach with lesson observations and local trainers). In this way, the CPD under analysis promoted changes and innovations in the schools that are in line with the finding from other author in different contexts (Avalos, 2011; Flores \& Simão, 2009; Villegas-Reimers, 2003) and also with previous initiatives in the country (Rosabal, 2005).The participants mentioned that the CPD programme improved the scientific subject specific skills of the teachers and promoted collaborative work among them. The agreement established between PASEG and the Ministry of Education to reduce the teacher timetables was stated to be an important contribution to the participation of the teachers in the CPD Programme.

The CPD programme gradually became a model for the professional development opportunity of the teachers on the school premises for long periods of time, following the findings of several studies (Avalos, 2011; Hardman et al., 2011; Hardman et al., 2015). The inclusion of the lesson observation was identified as a catalyst for the implementation of the training content and teaching aids by the teachers. This is in line with the findings of other authors (e.g. Guskey, 2002; O'Sullivan, 2006) and it stems from the fact that teachers change their attitudes and beliefs, when they see that an innovation works and, particularly, when they gain feedback or evidence (Guskey, 2002). The supervision used in this CPD programme follow Snow-Gerono (2008) approach were supervision is a dynamic process. It also overcomes the perspective that supervision is a control tool addressing the conclusion from a study conducted by De Grawe (2007). The priviest studies about CPD in the country found similar effects but regarding a CPD programme for kindergarten teachers.

The approval in the second phase of PASEG of the strategic concept for the teaching of Portuguese, as a second language in a multilingual context (PASEG undated), indicated an important change. This allowed the introduction of this approach in the CPD programme and we started to see the Portuguese language, as a strategy for an improvement in the quality of education. It also allowed, at least at a formal level, for the recognition of the linguistic diversity of Guinea-Bissau and the importance of other 
national languages in the education sector. This aspect is important because is the recognition of the particular characteristics of the local context (Avalos, 2011; Lundy, 2013) were language of instruction plays a key role (Barbosa \& Bizarro, 2011; Candé, 2008; Medeiros, 2005). This issue was absent in the beginning of the CPD programme.

All teachers clearly showed a willingness to learn. This fact seemed to be one of the reasons for the success of this CPD programme. In its own way the CPD programme also raised the morale of the teachers, which went beyond the material support. This goes in line with the three-layer model of the communities of practice (Hadar \& Brody, 2010) and the benefits of a CPD program that provide opportunities for teachers to learn for long periods of time (Hardman et al., 2011; Hardman et al., 2015; Haßler et al., 2015) and not follow a classic perspective of CPD in the global south - episodic teacher training not based in schools (Burns \& Lawrie, 2015).

We found that among the four schools the CPD programme produced more effects in School 1. This stemmed from the fact that this school is smaller than the others, is outside the capital city and, among other factors, all teachers of Portuguese language and mathematics were involved in the CPD programme. This seemed to indicate that the strategies in the schools in the capital city must be different from those in the interior of the country, that is a characteristic absent from the studies reviewed in chapter 2.1. Another issue that arose from this school was that the CPD programme only started in Phase 2 of PASEG, which also seems to indicate that the strategy adopted was more effective.

The results from this research point in the opposite direction to that of Campos and Furtado (2009). This stems from the fact that they stated that all the teacher training activities in the country had little impact on teaching practice. The CPD programme under analysis in this article seemed to have a strong impact on the practice of participating teachers. Nevertheless, some of the innovation introduced by this CPD programme (e.g. ICT, on-site CPD programme) hardly can continue without some kind of external support taking into consideration the fragility of the country and its education system

The CPD programme under analysis in this article points in the opposite direction of what has been common in similar contexts to Guinea-Bissau (Burns \& Lawrie, 2015). In fact, the Pedagogical Support Groups attempted to provide the opportunities for teachers to learn what is recommended in the literature reviewed above (e.g. Avalos, 2011; Geldenhuys \& Oosthuizen, 2015; Hardman et al., 2011; Hardman et al., 2015; Haßler et al., 2015). This fact is more evident from 2009 onwards after the restructuring of the Programme.

\section{Conclusion}

This study examined the experience of a bilateral educational aid continuing professional development (CPD) programme for teachers with specific reference to Guinea-Bissau. The CPD programme results point in the opposite direction to what has been commonly shown in similar contexts to Guinea-Bissau (Burns \& Lawrie, 2015). This stems from the fact that the Pedagogical Support Groups attempted to provide opportunities for teachers to learn what is recommended in the literature and common in higher performance countries (e.g. Avalos, 2011; Geldenhuys \& Oosthuizen, 2015; Hardman et al., 2011; Hardman et al., 2015; Haßler et al., 2015). In this way, this case study reveals that in contexts of protracted crises and fragility CPD programmes can offer opportunities for teachers to learn for long periods of time on a regular basis. However, some of the innovations introduced by this CPD programme (e.g. ICT, on-site CPD programme) hardly can continue without some kind of external support.

The teachers were unanimous in their perception that the core contribution of this CPD programme was their Portuguese language improvement and/or their 
confidence to speak it publicly. The teachers were also unanimous that the CPD programme allowed the schools to provide access to teacher development opportunities on the school premises and to a resource centre with ICT.

The study illustrated that the CPD programme promoted curricular mediation that went beyond the public schools that were the target of the programme. The CPD programme also raised the morale of teachers that went beyond the material support.

The inclusion of the lesson observations following the principles of pedagogical supervision is identified as a key factor for the implementation of the training content and teaching aids by the teachers. All teachers clearly showed a willingness to learn and improve their skills. This fact, in conjunction with the lesson observations and the didactical and pedagogical approach, seems to be the main reasons for the success of this CPD programme. In this way one of the main lessons to emerge from this study was that the CPD programme under analysis moved away from an ad hoc provision to a more systematic, longer term and sustainable approach.

From the data, it seems that strategies for large schools from big urban centres should be different from those of a smaller size and from the interior of the country.

In summary, the findings suggest that the CPD programme under analysis in this article had an impact on the teaching practices, thinking and morale of the participating teachers.

\section{Funding}

Part of this work was supported by the Foundation for Science and Technology, Portugal (Program POPH/FSE - grant number SFRH/BD/85561/2012 and CEECIND/01263/2017).

\section{Acknowledgements}

Thanks go to José Augusto Pacheco, Júlio Gonçalves dos Santos and Tony Lavender for their valuable comments and assistance in an earlier draft of this article.

\section{References}

Afonso, M., Magalhães, M., Ribeiro, M., \& Monteiro, H. (2008). Avaliação de três intervenções no sector da educação na Guiné-Bissau (2000-2007). Lisboa: IPAD.

Andersen, O. W. (2014). Some Thoughts on Development Evaluation Processes. IDS

Bulletin, 45(6), 77-84. http://doi:10.1111/1759-5436.12114

Andersson-Brolin, L., Catela, M. E., Fernandes, R. M., \& Liljeson, L. (1990). Assistência à educação num contexto de reforma: avaliação conjunta do apoio sueco ao sector da educação na Guiné-Bissau entre 1988 e 1990.Estocolmo: Swedish International Development Cooperation Agency.

Avalos, B. (2011). Teacher professional development in Teaching and Teacher Education over ten years. Teaching and Teacher Education, 27(1), 10-20. doi:http://dx.doi.org/10.1016/j.tate.2010.08.007

Aveleira, A. P. H. (2006). Melhorar a educação de infância na Guiné-Bissau. (Unpublished master's thesis). Universidade de Aveiro, Aveiro.

Bainton, D., Barrett, A., \& Tikly, L. (2016). Improving Secondary School Teacher Quality in Sub-Saharan Africa: Framing the Issues. (Bristol Working Papers in Education \#03/2016). Bristol: University of Bristol.

Barbosa, G., \& Bizarro, R. (2011). Educação para todos na Guiné-Bissau - que princípios metodológico-didácticos para a aula de língua Portuguesa? Paper presented at the COOPEDU — Congresso Portugal e os PALOP Cooperação na Área da Educação, Lisboa, Portugal.

Bardin, L. (2007). Análise de conteúdo. Lisboa: Edições 70. 
Barreto, A. G. (2012). Escolas comunitárias na Guiné-Bissau: sentidos, relações e mudanças.

(Unpublished master's thesis). ISCTE- Instituto Universitário de Lisboa, Lisboa.

Befani, B., Barnett, C., \& Stern, E. (2014). Introduction - Rethinking Impact Evaluation for Development. IDS Bulletin, 45(6), 1-5.

Befani, B., Ramalingam, B., \& Stern, E. (2015). Introduction - Towards Systemic Approaches to Evaluation and Impact. IDS Bulletin, 46(1), 1-6. https://doi.org/10.1111/1759-5436.12108

Benavente, A., \& Varly, P. (2010). Balanço de competências de docentes em exercício na Guiné-Bissau. Bissau: National Institute of Educational Development.

BERA. (2011). Ethical Guidelines for Educational Research. Retrieved from https://www.bera.ac.uk/wp-content/uploads/2014/02/BERA-EthicalGuidelines-2011.pdf

Burns, M., \& Lawrie, J. (2015). Where It's Needed Most: Quality Professional Development for All Teachers. New York: Inter-Agency Network for Education in Emergencies.

Campos, B., \& Furtado, A. (2009). Política Docente na Guiné-Bissau. Bissau: World Bank.

Candé, F. (2008). A língua portuguesa na formação de professores do ensino básico da região de Bafatá, na Guiné-Bissau. (Unpublished master's thesis). Universidade de Lisboa, Lisboa.

CEUM. (2012). Código de Conduta Ética da Universidade do Minho. Retrieved from http://www.sas.uminho.pt/uploads/codigo conduta etica_UM.pdf

Christie, P., Harley, K., \& Penny, A. (2010). Case studies from sub-Saharan Africa. In C. Day \& J. Sachs (Eds.), International handbook on the continuing professional development of teachers (pp. 167-190). Berkshire: Open University Press.

Cohen, L., Manion, L., \& Morrison, K. (2009). Research Methods in Education. New York: Routledge.

Coleman, J. (2014). Study of a Professional Development Initiative to Increase Cultural Competency. (Unpublished PhD thesis). Virginia Commonwealth University, Virginia.

Correia, H. H. (2013). O projeto africanidade e o contexto educacional da Guiné-Bissau. (Unpublished master's thesis). Universidade Federal da Paraíba, João Pessoa.

Costa, A. Q. d. (2014). O ensino de ciências em Guiné-Bissau: história, currículos e práticas. (Unpublished Bachelor thesis). Universidade Federal do Rio Grande do Sul, Porto Alegre.

Cá, C. M. O. (2005). A falta de formação pedagógica dos professores de Ensino Básico na Guiné-Bissau nos anos 1975-1986. (Unpublished Bachelor thesis). Universidade Estadual de Campinas, Campinas.

Daun, H. (1997). Teachers needs, culturally-significant teacher education and educational achievement in an African context - the case of Guinea-Bissau. International Journal of Educational Development, 17(1), 59-71. doi:http://dx.doi.org/10.1016/S0738-0593(96)00028-4

De Grauwe, A. (2007). Transforming School Supervision into a Tool for Quality Improvement. International Review of Education, 53(5/6), 709-714.

Dâmaso, M. F. R. (1997). Educação e formação de quadros na Guiné-Bissau. (Unpublished master's thesis). Instituto Superior de Ciências do Trabalho e da Empresa, Lisboa.

Feinstein, O., \& Beck, T. (2007). Evaluation of development interventions and humanitarian action. In I. F. Shaw, J. C. Greene, \& M. M. Mark (Eds.), Handbook of evaluation. Policies, Programs and Practices. (pp. 536-558). Londres: Sage Publications. 
Flores, M., \& Simão, A. (2009). Aprendizagem e desenvolvimento profissional de professores: contextos e perspectivas. Mangualde: Edições Pedago.

Freire, P. (1984). Cartas à Guiné-Bissau: registos de uma experiência em processo. Rio de Janeiro: Terra e Paz.

Furtado, A. (2005). Administração e Gestão da Educação na Guiné-Bissau: Incoerências e Descontinuidades. (Unpublished $\mathrm{PhD}$ thesis). Universidade de Aveiro, Aveiro.

Geldenhuys, J. L., \& Oosthuizen, L. C. (2015). Challenges influencing teachers' involvement in continuous professional development: A South African perspective. Teaching and Teacher Education, 51, 203-212. doi:http://dx.doi.org/10.1016/j.tate.2015.06.010

Glickman, C., \& Gordon, S., Ross-Gordon, J. (1998). Supervision of Instruction: a developmental approach. Boston: Allyn \& Bacon.

Guskey, T. R. (2002). Professional Development and Teacher Change. Teachers and

Teaching, 8(3), 381-391. https://doi.org/10.1080/135406002100000512

Hadar, L., \& Brody, D. (2010). From isolation to symphonic harmony: Building a professional development community among teacher educators. Teaching and Teacher Education, 26(8), 1641-1651. doi:https://doi.org/10.1016/j.tate.2010.06.015

Hardman, F., Ackers, J., Abrishamian, N., \& O’Sullivan, M. (2011). Developing a systemic approach to teacher education in sub-Saharan Africa: emerging lessons from Kenya, Tanzania and Uganda. Compare: A Journal of Comparative and International Education, 41(5), 669-683. https://doi.org/10.1080/03057925.2011.581014

Hardman, F., Hardman, J., Dachi, H., Elliott, L., Ihebuzor, N., Ntekim, M., \& Tibuhinda, A. (2015). Implementing school-based teacher development in Tanzania.

Professional Development in Education, 41(4), 602-623. https://doi.org/10.1080/19415257.2015.1026453

Haßler, B., Hennessy, S., Cross, A., Chileshe, E., \& Machiko, B. (2015). School-based professional development in a developing context: lessons learnt from a case study in Zambia. Professional Development in Education, 41(5), 806-825. https://doi.org/10.1080/19415257.2014.938355

INEE. (2009). INEE Guidance Notes on Teacher Compensation in Fragile States, Situations of Displacement and Post-Crisis Recovery. New York: Inter-Agency Network for Education in Emergencies.

IPAD. (2011). Cooperação Portuguesa: Uma leitura dos últimos quinze anos de cooperação para o desenvolvimento. Lisboa: IPAD.

Landim, R., \& Bamba, M. (1994). Estudo de seguimento e avaliação da formação em serviço de professores do ensino básico. Bissau: National Institute of Educational Development.

Landim, R. C. (2010). Relatório de investigação sobre mecanismos de gestão escolar e a sua influência na qualidade de ensino na Guiné-Bissau. Bissau: National Institute of Educational Development.

Lepri, J.-P. (1988). Formação de professores, locais, materiais escolares e insucesso escolar. Soronda : revista de estudos guineenses (5), 83-102.

Lopes, J., \& Silva, H. (2010). O professor faz a diferença. Lisboa: Lidel.

Lundy, B. D. (2013). Cabral and Freire: The Importance of Cultural Capital in ReBuilding a Successful Education System in Guinea-Bissau. In F. Manji \& B. F. Jr. (Eds.), (pp. 365-378). Dakar: CODESRIA/Daraja Press.

Lundy, B. D. (2018). Rebuilding Tertiary Education in Guinea-Bissau: Can it be done? FIRE: Forum for International Research in Education, 4(3), 169-190. doi:https://doi.org/10.32865/fire2018433 
Medeiros, V. (2005). Desenvolvimento educativo e formação de professores na GuinéBissau. In M. H. M. Mateus \& L. T. Pereira (Eds.), Língua portuguesa e cooperação para o desenvolvimento. (pp. 79-85). Lisboa: Colibri.

Monteiro, J. (2005). A Educação na Guiné Bissau: Bases para uma estratégia sectorial renovada. Bissau: Ministry of Education.

Namoni, J. (1994). Avaliação de livro escolar matemática, Programa e guia do professor. - $1 .{ }^{a}$ classe. Bissau: National Institute of Educational Development.

Oliveira, J. (2014). Kit;Energia, Ambiente e Sustentabilidade: uma estratégia para a promoção da Ciência na Guiné-Bissau. (Unpublished PhD thesis). Universidade do Minho, Braga.

Oliveira, J., Lanceros-Mendez, S., Neves, L., \& Santos, J. G. d. (2012). Kit; Energia Ambiente e Sustentabilidade: uma proposta para a promoção da educação ceintífica na Guiné-Bissau. Paper presented at the II Coopedu - África e o Mundo. Lisboa, Portugal.

O’Sullivan, M. (2006). Lesson observation and quality in primary education as contextual teaching and learning processes. International Journal of Educational Development, 26(3), 246-260. doi:http://dx.doi.org/10.1016/j.ijedudev.2005.07.016

PASEG. (2007). Oficinas em movimento. In (Vol. 2). Bissau: PASEG.

Pereira, P., \& Namoni, J. (1994). O ensino-aprendizagem da matemática no ensino básico. Retrieved Bissau: National Institute of Educational Development.

Picciotto, R. (2014). Have Development Evaluators Been Fighting the Last War... And If So, What is to be Done? IDS Bulletin, 45(6), 6-16. https://doi.org/10.1111/1759-5436.12109

Pityana, N. B. (2013). Cabral, Culture and Education. In F. Manji \& B. F. Jr. (Eds.), Claim No Easy Victories: The Legacy of Amilcar Cabral (pp. 379-396). Dakar: CODESRIA/Daraja Press.

Portugal, G., \& Aveleira, A. P. H. (2007). Melhorando e apoiando práticas de qualidade em Educação de Infância na Guiné-Bissau: numa dinâmica de formação, surpervisão e avaliação. Contrapontos, 7(2), 407-423.

Portugal, M. G., \& Aveleira, A. P. (2009). Supporting Early Childhood Teachers in Guinea-Bissau. Journal of Early Childhood Teacher Education, 30(3), 210-219. https://doi.org/10.1080/10901020903084140

Robson, C. (2011). Real world research: a resource for social scientists and practitionerresearchers. Chichester: Wiley.

Rosabal, M. (2005). Avaliacao Final do Programa de Reactivacao e Aperfeicoamento das COME. Bissau: Ministry of Education.

Santos, J., Silva, R. d., \& Mendes, C. (2012). Culturas de apoio a Professores em contexto de fragilidade educativa: Algumas reflexões e lições da Guiné-Bissau. Paper presented at the II Coopedu - África e o Mundo, Lisboa, Portugal.

Santos, J., Silva, R. d., \& Mendes, C. (2014). PASEG II - uma aposta contínua na qualidade e inovação educativa na Guiné-Bissau. Africana Studia(22), 59-72.

Silva, R. d., \& Oliveira, J. (2017). 40 years of educational research in Guinea-Bissau: Mapping the terrain. International Journal of Educational Development, 57, 21-29. doi:https://doi.org/10.1016/j.ijedudev.2017.09.003

Snow-Gerono, J. L. (2008). Locating supervision-A reflective framework for negotiating tensions within conceptual and procedural foci for teacher development. Teaching and Teacher Education, 24(6), 1502-1515. doi:http://dx.doi.org/10.1016/j.tate.2008.02.002

UNESCO. (2014). Teaching and learning: Achieving quality for all. Retrieved from Paris: 
Villegas-Reimers, E. (2003). Teacher Professional Development: an international review of the literature. Paris: UNESCO-IIEP.

Wenger, E., \& Wenger-Trayner, B. (2015). Communities of practice. A brief

introduction. Retrieved from http://wenger-trayner.com/introduction-tocommunities-of-practice/

\begin{abstract}
About the Authors
Rui da Silva is a researcher, president from the Board o and coordinator of the research group Education, Development and Global Citizenship. from the Center for African Studies of the University of Porto. Currently is developing a research project "Comparative study on the compulsory education privatization in small states: examining the role and impact in Cape Verde and Guinea-Bissau" funded by the Foundation for Science and Technology. Worked as a researcher, consultant and education specialist in projects in Angola, Cape Verde, Guinea-Bissau, Timor-Leste and South Sudan. Founding member of the Lusophone Network for the Right to Education (ReLus). The research interests include the relations between the public and the private in education, evaluation of effects and impacts of humanitarian aid and development assistance projects; globalization and curriculum, educational change, and cross-cultural transfers. Dr. da Silva's webpage is: http://rdasilvaxhome.wordpress.com/

Joana Oliveira is an Assistant Professor from the College of Education at the Polytechnic Institute of Viana do Castelo and a researcher from the Center for African Studies at the University of Porto. She has a degree in Biology (educational branch) from the University of Coimbra, a Master's in environmental sciences, and a PhD in Sciences from the University of Minho. She has done a postdoctoral degree in Education - specializing in Environmental Education and Sustainability. She worked as a researcher and consultant in projects in Angola, Guinea-Bissau and Timor-Leste. She coordinates the master's degree in preschool education and primary education teaching and teaches graduation and master's degree courses to pre-service and in-service teachers. Since 2004, she has been working with the Unit of Education and Development Studies in development assistance and global citizenship education. Her research interests include teacher professional development, global citizenship education, outdoor education, and local heritage.
\end{abstract}

